\title{
Effect of intensity and frequency of defoliation on growth of ryegrass, tall fescue and phalaris
}

\author{
J.J. Kerrisk' and N.A. Thomson ${ }^{2}$ \\ 'Taranaki Agricultural Research Station, \\ MAFTech, Nonnanby \\ ${ }^{2}$ Flock House Agricultural Research Centre, \\ MAFTech, Bulls
}

\begin{abstract}
Pasture growth rates of ryegrass, tall fescue and phalaris were compared under combinations of 2 defoliation heights and 3 defoliation frequencies in mowing trials run in spring, summer, autumn and winter over 2 years. Lax defoliation gave on average $15 \%, 20 \%$ and $21 \%$ higher pasture growth rates than intense defoliation for ryegrass, tall fescue and phalaris pastures respectively over all seasons. Climate had a major influence on the response of all three pastures to defoliation management. In a dry spring, tall fescue produced most from a 15 -day cutting interval while for ryegrass and phalaris production was greatest from a 30day interval. In a wet spring, cutting frequency had no effect, but a significant $(\mathrm{P}<0.01)$ interaction between height and frequency of defoliation occurred for all three pastures. In dry summer and autumn seasons, production was greatest under a 10- to 15-day interval for ryegrass and tall fescue, but phalaris was not affected by defoliation frequency. In a dry winter, phalaris had highest growth rates under a 45day defoliation interval while the other two species were unaffected. In wet seasons defoliation management had little effect on growth rates. For maximum growth, defoliation management of tall fesuce differs from that of ryegrass in spring, while management of phalaris for maximum growth differs from that of ryegrass in winter.
\end{abstract}

Keywords growth rates, ryegrass, tall fescue, phalaris, defoliation height, defoliation frequency, climate

\section{INTRODUCTION}

Because tall fescue and phalaris tolerate drought and grass grub attack (Kain et al. 1977; McCallum 1990), they have been considered suitable for dairy pastures in the Taranaki environment. The two species differ from ryegrass in growth habit, being more clumpy and upright, and preliminary work in Taranaki (Goold et al. 1985) has shown they are more productive under the same management as ryegrass. However, given the different growth habit of tall fescue and phalaris in comparison with ryegrass, growth may be optimal under a different defoliation management

This trial is a preliminary investigation to determine how defoliation management affects the performance of tall fescue, phalaris and ryegrass, and looks at the implications for their management for maximum DM production.

\section{METHODS}

The trial was established to compare, under standardised defoliation height and frequency treatments, the immediate regrowth of three pasture types: ryegrass/white clover, tall fescue/white clover and phalaris/white clover. The three pasture types were established at the Taranaki Agricultural Research Station for the farmlet trial reported by Thomson et al. (1988). The cutting heights and frequency trial was superimposed on individual paddocks of the respective species within the lowstocked treatments of the farmlet study.

The study reported in this paper was run over 2 years (19851987) and in each season, short-term trials were run concurrently on the three pasture types. Trial duration in spring, summer and autumn was 30 days and in winter 90 days. Each trial comprised a factorial design of 2 cutting heights and 3 cutting frequencies to give 6 treatments each replicated 4 times. Defoliation treatments were applied with a rotary mower and DM production measured by the electronic pasture probe* using the difference technique. Trials were laid down on a new area of the respective paddocks each season. The low cutting height (Lo) defoliated pasture to 4 $\mathrm{cm}$ above ground level in spring, summer and autumn and to $3 \mathrm{~cm}$ in winter. The high cutting height (Hi) was $5.5 \mathrm{~cm}$ above ground level in spring, summer and autumn and $4.5 \mathrm{~cm}$ in winter. Cutting frequencies were 10 days, 15 days and 30 days in spring, summer and autumn and 30,45 and 90 days in winter. These defoliation intervals were respectively termed frequent $(\mathrm{F})$, medium $(\mathrm{M})$ and infrequent (I).

Nutrients removed were replaced by a compound NPK fertiliser in the $\mathrm{M}$ and $\mathrm{F}$ treatments. Herbage dissection samples were taken at the termination of each trial and assessed for sown species, other grasses, clover, weed and dead matter.

*Design Electronics Palmerston North 
Table 1 Climatic conditions for the duration of the trial recorded at the Taranaki Agricultural Research Station

\begin{tabular}{|c|c|c|c|c|c|c|c|c|}
\hline \multirow[b]{2}{*}{ Year } & \multicolumn{4}{|c|}{ Rainfall (mm) } & \multicolumn{4}{|c|}{ Mean Temperatures ("C $\mathrm{C})$} \\
\hline & Spring & Summer & Autumn & Winter & Spring & Summer & Autumn & Winter \\
\hline 19851986 & 224 & 514 & 228 & 341 & 11.4 & 17.3 & 13.4 & 8.3 \\
\hline $1986-1987$ & 249 & 218 & 271 & 165 & 11.8 & 16.2 & 12.5 & 9.0 \\
\hline 10 year average & 259 & 230 & 261 & 308 & 11.5 & 16.2 & 13.2 & 8.9 \\
\hline
\end{tabular}

\section{RESULTS}

\section{Climate}

Table 1 summarises the average rainfall and temperatures for each season over the trial period. The main differences between the two years were the dry spring in 1985 , the very dry summer of 1986-87 and the dry winter of 1987.

\section{Pasture composition}

Throughout the trial, pasture composition (Table 2) of the three pastures remained relatively constant as no treatment effects were observed.

Table 2 Average pasture composition of ryegrass, tall fescue and phalaris pastures over 2 years ( $\%$ Dry Wt.)

\begin{tabular}{lcccc}
\hline & $\begin{array}{c}\text { Sown } \\
\text { species }\end{array}$ & Clover & $\begin{array}{c}\text { Dead } \\
\text { matter }\end{array}$ & $\begin{array}{c}\text { Weeds \& } \\
\text { other }\end{array}$ \\
grasses
\end{tabular}

\section{Species effects}

The average growth rates of the three species in spring was similar (Table 3). In summer and autumn the average growth rate of tall fescue and phalaris was $30-40 \%$ higher than ryegrass. However, when wet and dry seasons are compared, differences between tall fescue and phalaris become apparent, In summer 1985-86 and autumn 1987 (wet seasons), the growth rate of tall fescue was greater than that of ryegrass and phalaris. In autumn 1986 and summer 1986-87 (dry seasons), both tall fescue and phalaris had higher growth rates than ryegrass, particularly phalaris with double the growth rate of ryegrass.

\section{Cutting height}

Ryegrass, tall fescue and phalaris had significantly higher average growth rates under the high $(\mathrm{Hi})$ cutting height than the low (Lo) by $30 \%$ in spring and $20 \%$ in summer and autumn (Table 4). In winter, only tall fescue responded significantly to cutting height.

\section{Cutting frequency}

The effect of cutting frequency on growth rates (Table 5) differed in each of the two years.

Year 1 In spring, ryegrass and phalaris produced significantly more under infrequent (I) defoliation while tall fescue produced significantly more under medium defoliation (M). In summer, autumn and winter the only significant response to defoliation frequency was shown by ryegrass in autumn. This autumn was very dry (Table 1) and the growth of ryegrass was greatest under frequent (F) defoliation.

Year 2 In spring, cutting frequency had no effect on the growth of the three species, but the interaction between defoliation height and frequency (Table 6) was significant for all species. In summer (a dry season) both ryegrass and tall fescue were significantly more productive under the $F$ frequency while phalaris was unaffected by frequency. In autumn, cutting frequency had no effect on any of the species. In winter (drier than the first year), phalaris produced significantly more under the $M$ frequency while ryegrass and tall fescue grew at a similar rate at all frequencies.

\section{DISCUSSION}

Pasture growth was determined by the difference in total herbage mass (assessed to ground level) over set time intervals using the electronic pasture probe calibrated for pasture type and time of year. Through using this technique it was found that ryegrass, tall fescue and phalaris responded in a similar manner to defoliation height over spring, summer and autumn, with high cutting resulting in significantly higher pasture growth than low cutting.

Table 3 Seasonal effects on daily growth rates $(\mathrm{kg} \mathrm{DM} / \mathrm{ha})$ of tall fescue, and phalaris relative to ryegrass.

\begin{tabular}{crrrrrrrr}
\hline & \multicolumn{3}{c}{ Average of 2 years } & & \multicolumn{2}{c}{ Summer } & \multicolumn{2}{c}{ Autumn } \\
& Spring & Summer & Autumn & Wintes & 1985-6 & $1986-7$ & 1986 & 1987 \\
\hline Ryegrass (kg/ha/day) & $\mathbf{7 5}$ & $\mathbf{3 6}$ & $\mathbf{3 7}$ & $\mathbf{2 4}$ & $\mathbf{5 2}$ & 19 & $\mathbf{2 6}$ & $\mathbf{4 8}$ \\
$\%$ & 100 & 100 & 100 & 100 & 100 & 100 & 100 & 100 \\
Tall fescue (\% of ryegrass) & 104 & 139 & 138 & 118 & 132 & 157 & 143 & 134 \\
Phalaris (\% of rvegrass) & 106 & 133 & 140 & 132 & 109 & 198 & $\mathbf{2 0 5}$ & 105 \\
\hline
\end{tabular}


Table 4 Pasture daily growth rate $(\mathrm{kg} \mathrm{DM} / \mathrm{ha})$ response to cutting height; mean of 2 years' data

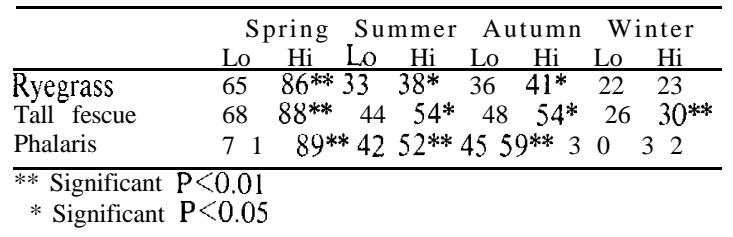

In winter the growth of phalaris and ryegrass was unaffected by cutting height, but in both winters the growth of tall fescue pastures was increased by high cutting.

Morris (1970) found a similar effect of cutting height on the production of ryegrass pastures when measured as differences in total herbage mass but not when measured as growth above cutting height Other workers (Reid 1966; Clark et al. 1974; Fulkerson et al. 1986) found that the harvested DM production of ryegrass pastures (DM production above mower height) was greatest from intense defoliation when harvested infrequently. Brougham (196 1) and Harris (197 1) suggested that the response to cutting height may differ between species and would be critical over summer. These findings were not apparent in this trial and indicate that the interpretation of plot trials investigating the effects of defoliation management must take into account measurement and trial techniques.

Pasture growth of all three species appeared to be less affected by the interval between defoliation than height of defoliation. However, the effect of defoliation interval on the growth of the three pasture types differed according to season and climate. In wet seasons under high cutting the frequency of defoliation had no effect on the growth of ryegrass, tall fescue and phalaris pastures.

The interaction between cutting height and frequency (Table 6) for each species in spring 1986 implies that frequency of defoliation is critical for growth at a low defoliation but not at a high defoliation. Similar interactions between defoliation height and frequency for ryegrass pastures have been observed throughout the year (Reid 1966; Morris 1970; Clark et al. 1974), but in our trial the interaction occurred only in spring of one year.

In the previous spring (a drier spring) an increasing interval between defoliations at both low and high cutting significantly increased ryegrass growth. Over the remainder of the wet seasons defoliation interval had no effect on ryegrass growth. However, in a dry summer and autumn, ryegrass growth was significantly greater under frequent defoliation ( $10-15$ days). This finding is contrary to recommendations made on ideal grazing management of dairy pasture when a 30 - increasing to 50 day grazing rotation is recommended. Also it is contrary to the work by Tainton (1974) who reported the growth of ryegrass pastures over a dry summer to be greater under an infrequent, lax defoliation. In dry seasons tall fescue and phalaris responded to defoliation frequency differently to ryegrass.

The management of tall fescue differed from ryegrass in two seasons. In a dry spring maximum growth was recorded under a 15-day cutting interval

Table 6 Interactions between cutting height and frequency in spring 1986 (kg DM/ha/day, LSD lettering)

\begin{tabular}{lccccccc}
\hline & & & & & \multicolumn{3}{c}{$\begin{array}{c}\text { Significance } \\
\text { of }\end{array}$} \\
\hline Ryegrass L & o & $63 \mathrm{~A}$ & $70 \mathrm{~A}$ & $89 \mathrm{~B}$ & $* *$ \\
& $\mathrm{Hi}$ & $92 \mathrm{~B}$ & $108 \mathrm{C}$ & $87 \mathrm{~B}$ & \\
\multirow{5}{*}{ Tall fescue } & Lo & $78 \mathrm{~A}$ & $93 \mathrm{~B}$ & $107 \mathrm{C}$ & $* *$ \\
& $\mathrm{Hi}$ & $111 \mathrm{C}$ & $122 \mathrm{D}$ & $113 \mathrm{C} \mathrm{D}$ & \\
Phalaris & Lo & $62 \mathrm{~A}$ & $71 \mathrm{~A}$ & 94 & $\mathrm{~B}$ & $* *$ \\
& $\mathrm{Hi}$ & 9 & 8 & $\mathrm{~B}$ & $103 \mathrm{~B}$ & $100 \mathrm{~B}$ & \\
\hline
\end{tabular}

** Signiticance $\mathrm{P}<0.01$

Table 5 Pasture daily growth rate ( $\mathrm{kg} \mathrm{DM} / \mathrm{ha} / \mathrm{day})$ response to cutting frequency.

\begin{tabular}{|c|c|c|c|c|c|c|c|c|c|c|c|c|c|c|c|c|}
\hline \multirow[t]{2}{*}{$\begin{array}{l}\text { Year I } \\
\end{array}$} & \multicolumn{4}{|c|}{ Spring (dry) } & \multicolumn{4}{|c|}{ Summer (wet) } & \multicolumn{4}{|c|}{ Autumn (dry) } & \multicolumn{4}{|c|}{ Winter (wet) } \\
\hline & $\mathrm{F}$ & $\mathrm{M}$ & I & LSD* $^{*}$ & $\mathrm{~F}$ & $\mathrm{M}$ & I & LSD* & $\mathrm{F}$ & $\mathrm{M}$ & I & LSD* & $\mathrm{F}$ & $\mathrm{M}$ & $\mathrm{I}$ & LSD* \\
\hline Ryegrass & 57 & 66 & 73 & 8.9 & 54 & 56 & 47 & & 31 & 25 & 23 & 4.0 & 15 & 16 & 14 & NS \\
\hline Táll fescue & 45 & 59 & 43 & 7.2 & 69 & 74 & 65 & & 41 & 41 & 30 & - & 24 & 24 & 26 & \\
\hline Phalaris & 54 & 76 & 84 & 13.5 & 52 & 61 & 58 & & 49 & 54 & 56 & & 18 & 18 & 20 & \\
\hline \multirow[t]{2}{*}{ Year 2} & \multicolumn{4}{|c|}{ Spring (wet) } & \multicolumn{2}{|c|}{ Summer } & \multicolumn{2}{|c|}{ (dry) } & \multicolumn{2}{|c|}{ Autumn } & \multicolumn{2}{|c|}{ (wet) } & \multicolumn{4}{|c|}{ Winter (dry) } \\
\hline & $\mathrm{F}$ & $\mathrm{M}$ & I & LSD* & $\mathrm{F}$ & M & I & LSD* & $\mathrm{F}$ & $\mathrm{M}$ & & $\mathrm{LSD}^{*}$ & $\mathrm{~F}$ & M & 1 & LSD* \\
\hline Rycgraas & 78 & 89 & 88 & & 20 & 20 & 16 & 2.5 & 50 & 51 & 43 & & 30 & 36 & 30 & \\
\hline Tall fescue & 95 & 107 & 110 & & 35 & 28 & 27 & 6.0 & 65 & 64 & 65 & & 29 & 33 & 30 & \\
\hline Phalaris & 80 & 87 & 97 & & 35 & 37 & 41 & & 53 & 50 & 49 & & 36 & 52 & 42 & 7.2 \\
\hline
\end{tabular}

$\mathrm{LSD}^{*} \mathrm{P}<0.05$

$\mathrm{F}=$ Frequent cutting frequency

$\mathrm{M}=$ Medium cutting frequency

I =- Infrequent cutting frequency 
and in autumn cutting interval had no effect on growth. For phalaris in comparison with ryegrass over a dry summer and autumn, defoliation interval had no effect, but in winter growth was maximum on a medium interval (45 days). These results suggest that for maximum growth the grazing management of tall fescue and phalaris pastures would differ from that recommended for ryegrass, the differences being more critical in a dry season.

Pasture composition was not significantly affected by either the intensity or the frequency of defoliation, due most likely to the short term nature of the trials and no carry-over effects being measured.

\section{CONCLUSIONS}

Lax defoliation gives significantly higher growth rates than intense defoliation in spring, summer and autumn for ryegrass, tall fescue and phalaris pastures. In winter greater growth for tall fescue was recorded under a lax defoliation. For ryegrass and phalaris the intensity of cutting had no effect on winter growth.

The results of this trial imply that:

- In spring tall fescue should be defoliated every 15 days, ryegrass and phalaris every 30 days.

- In drier than average summers and autumns, the frequency of defoliation of ryegrass and tall fescue is important, a 10-day interval giving greatest growth rates; the defoliation interval of phalaris is less important.

- In dry winters, management of phalaris may be important, greatest production resulting from defoliation every 45 days. The frequency of defoliation of ryegrass and tall fescue has no effect on production.

\section{REFERENCES}

Brougham, R.W., 1961. Some factors affecting the persistency of short rotation ryegrass. NZ Journal of Agricultural Research 2: 1232-48.

Clarke, J.; Kat, C.; Santhirasegaram, K. 1974. The effects of changes in heights of cutting and growth in the digestible organic matter production and botanical composition of perennial pasture. Journal of the British G rassland Society 29:269.

Fulkerson, W.J.; Michell, P.J. 1987. The effect of height and frequency of mowing on the yield and composition of perennial ryegrass/white clover swards in the autumn to spring period. Grass and Forage Science 42:169174.

Goold, G.J. et a/. 1985. Agronomic and environmental constraints in North Island Dairying and the choice of pasture species. 'Using Herbage Cultivars'. Grassland Research and Practice Series No. 3, NZ Grassland Association.

Harris, W. 1971 . The effects of density, cutting height and white clover (Trifolium repens L.) on the structure of a ryegrass (Lolium spp) population. Journal of Agricultural Science, Cambridge 77:385-395.

Kain, W.M.; Atkinson, D.S. 1977. Development of resistant pastures and methods of pasture management for grass grub (Costelytra zealandica (White)) control. NZ Journal of Agricultural Research 21:501-517.

$\mathrm{McC}$ allum et al. 1990. Grass grub tolerant pastures and fettiliser nitrogen as an alternative to white clover in pastures subject to grass grub attack. Proceedings of the NZ Grassland Association 5 1:00-00.

Morris, R.M. 1970. Use of cutting treatments designed to simulate the defoliation process under sheep grazing. Journal of British Grassland Association 25: 198206.

Reid, D. 1966. Studies in the cutting management of grass/ clover swards for the effects of close and lax cutting on yield of herbage from swards cut at different frequencies. Journal of Agricultural Science, Cambridge 66:101-106.

Tainton, N.M. 1974. Effects of different grazing rotations on pasture production. Journal of the British Grassland Society 29:191-202.

Thomson N.A. et al. 1988. An evaluation of Grasslands Roa tall fescue and Grasslands Maru Phalaris for dairying. Proceedings of the NZ Grassland Association 49:187-191. 